\title{
Fat Body Morphology of Eriopis connexa (Coleoptera, Coccinelidae) in Function of Two Alimentary Sources
}

\author{
Renato de Almeida Sarmento ${ }^{1}$, Hamilton Gomes de Oliveira ${ }^{1}$, Anderson Mathias Holtz ${ }^{1}$, \\ Solange Marques da Silva ${ }^{1}$, José Eduardo Serrão ${ }^{2 *}$ and Ângelo Pallini ${ }^{1}$ \\ ${ }^{I}$ Departamento de Biologia Animal; Setor de Entomologia; Universidade Federal de Viçosa; 36571-000; Viçosa - \\ MG - Brazil. ${ }^{2}$ Departamento de Biologia Geral;Universidade Federal de Viçosa; 36571-000; Viçosa - MG - Brazil
}

\begin{abstract}
This work investigated the influence of two alimentary sources: aphids and mites, in the morphology of the fat body of E. connexa. Results showed that fat body cells of individuals fed with aphids presented areas more than three folds higher $\left(511 \pm 98,7 \mu^{2}\right)$ than those of beetles fed with mites $\left(162 \pm 34,9 \mu m^{2}\right)$. Histochemical tests showed that nutrient amount stored in fat body was higher in lady-beetles fed on aphids.
\end{abstract}

Key words: Alimentary source, aphids, Eriopis connexa, fat body, mites

\section{INTRODUCTION}

The coccinelids, insects known as lady-beetles, are effective agents in the arthropod control, acting as predator of pest (Hagen 1976). They constitute an most efficient agent in the control of aphids (Hagen 1962; Hodek 1973). Among coccinelids, Eriopis connexa has a prominence position in the control of aphids (Santos and Pinto. 1981). Hodek (1973) have pointed out that E. connexa was one of the responsible species for the maintenance of the aphids' population in alfalfa (Medicago sativa L.) below control level. Holling (1961) stated that predation was a complex act, affected by basic factors, such as the densities of the prey and predator and by secondary factors involving the characteristics of the environment of the prey and of the predator.

Nutrients obtained from feeding are stored partly in the fat body, which is considered a multifunctional organ, because it acts in various metabolic processes with a high biosynthetic activity during insect lifespan (Levenbook 1985). Syntheses of proteins of the haemolymph, lipid substances including hormones, detoxification through the storage of the metabolism products and storage of lipid and carbohydrates are functions of the fat body (Chapman 1998; Qin et al. 1997; Cruz-Landim 1985).

In Brazil, researches on E. connexa are restrict to its occurrence only (Pimenta and Smith 1976; Gassen 1986). Hence, the purpose of this work was to investigate the influence of two alimentary sources: aphids and mites, in the morphology of the fat body of E. connexa in order to find out the predation habits of this beetle.

\section{MATERIALS AND METHODS}

Adults of Eriopis connexa were collected in field, transferred to laboratory and maintained at $25^{\circ} \mathrm{C}$

\footnotetext{
* Author for correspondence
} 
and relative humidity of $70 \%$. Five couples $E$. connexa were placed in plastic cups $(500 \mathrm{ml})$ with plastic cover containing a hole in the center substituted by a nylon mesh. Eggs were removed and placed in Petri dishes $(5 \times 1.5 \mathrm{~cm})$ until hatching and larvae were individualized in Petri dishes. As alimentary sources for the larvae and adults of E. connexa aphids were used (Myzus persicae), obtained from tomato plants in the Federal University of Viçosa (UFV) and mites (Tetranychus evansi) obtained from massive rearing of the Acarology laboratory UFV. The insects were maintained individually in the plates and fed ad libidum.

Seven days after adult emergence, three males and females were dissected in $125 \mathrm{mM} \mathrm{NaCl}$. Fat body fragments were transferred to $4 \%$ paraformaldehyde, in phosphate buffer $(0.1 \mathrm{M} \mathrm{pH}$ 7.2). Pieces were dehydrated in ethanol series (70, 80 and 95\%), embedded in historesin (Leica) and 6-10 $\mu \mathrm{m}$ sections were obtained. Sections were stained with tuluidine blue and some sections were submitted to the following histochemical tests: Mercury Bromophenol blue for total proteins, PAS for neutral carbohydrates and Nile blue for neutral and acidic lipids. Measurements of trophocytes areas (16 sections per specimen) were obtained using the software Image-Pro Plus, version 4.0 (Media Cybernetics).

\section{RESULTS AND DISCUSSION}

Fat body cells of individuals fed with aphids presented areas more than 3-folds higher (511 \pm $98.7 \mu \mathrm{m}^{2}$ ) than those cells of individuals fed with mites $\left(162 \pm 34.9 \mu \mathrm{m}^{2}\right)$. In relation to trophocytes morphology, there were significant differences. In lady-beetles fed on aphids, the fat body cells were well developed with many granules and vacuoles of various size in the cytoplasm, while in mite fed specimens, trophocytes were small with cytoplasm showing a fine and uniform granulation without vacuoles (Figs. 1, 2). Bromophenol blue analysis showed that aphids fed specimens presented strong positive reactions placed among the vacuoles which were little reactive, while in mite fed ladybeetles weakly positive reaction, restricted to a few granules (Figs. 3, 4) were observed.

In both diets, oenocytes were strongly positives. PAS reaction showed strongly positively in trophocytes cytoplasm among vacuoles for specimens fed with aphids, while in those fed with mites the reactivity was weak and placed in a few cytoplasm areas (Figs. 5, 6).

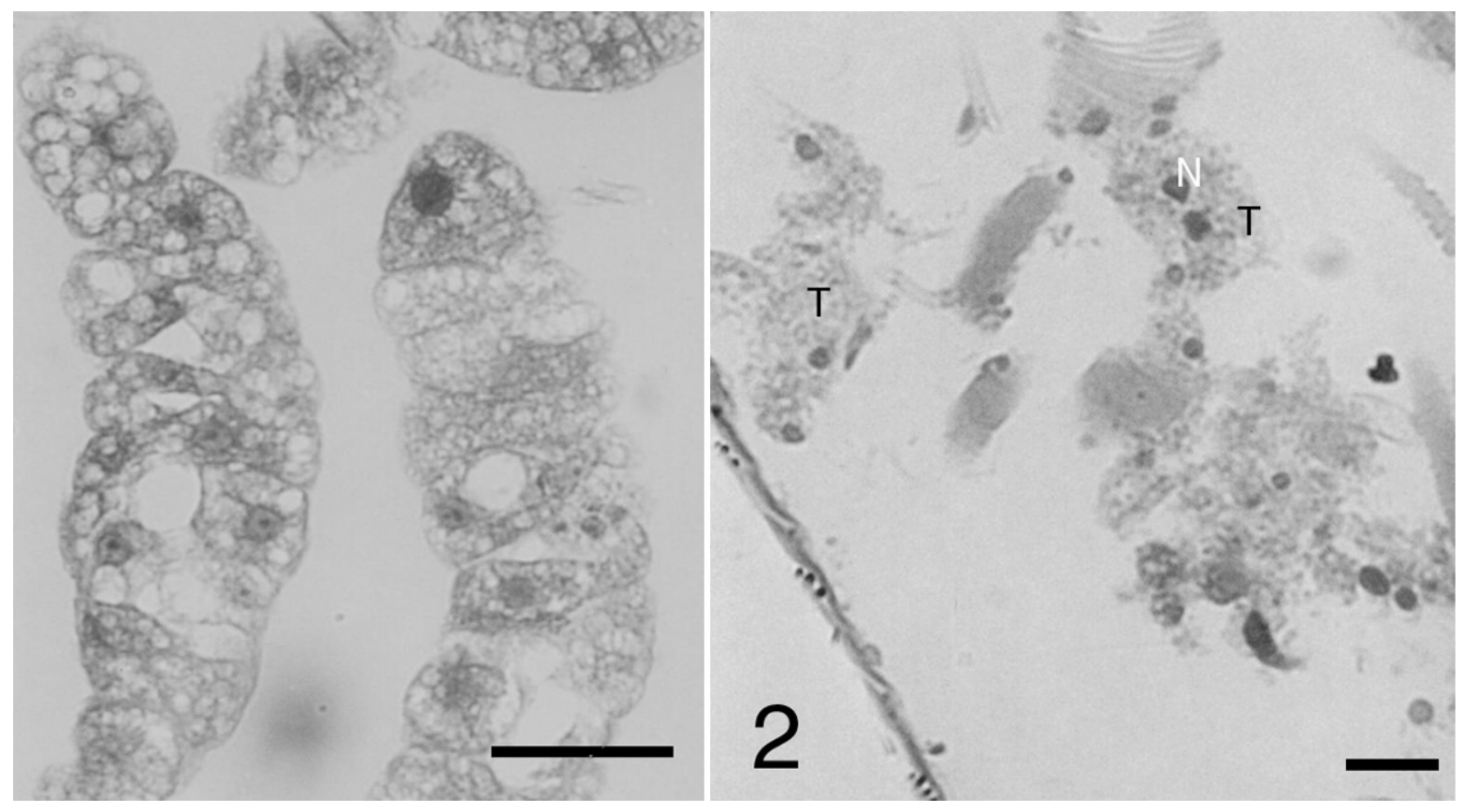

Figures 1-2 - Fat body of Eriopis connexa toluidine blue stained. 1. Specimen fed with Myzus persicae. Notice well developed trophocytes (T) with large vacuoles (v). 2. Specimens fed on Tetranychus evansi showing trophocytes $(\mathrm{T})$ without vacuoles. N - trophocyte nucleus. Bars $=15 \mu \mathrm{m}$. 


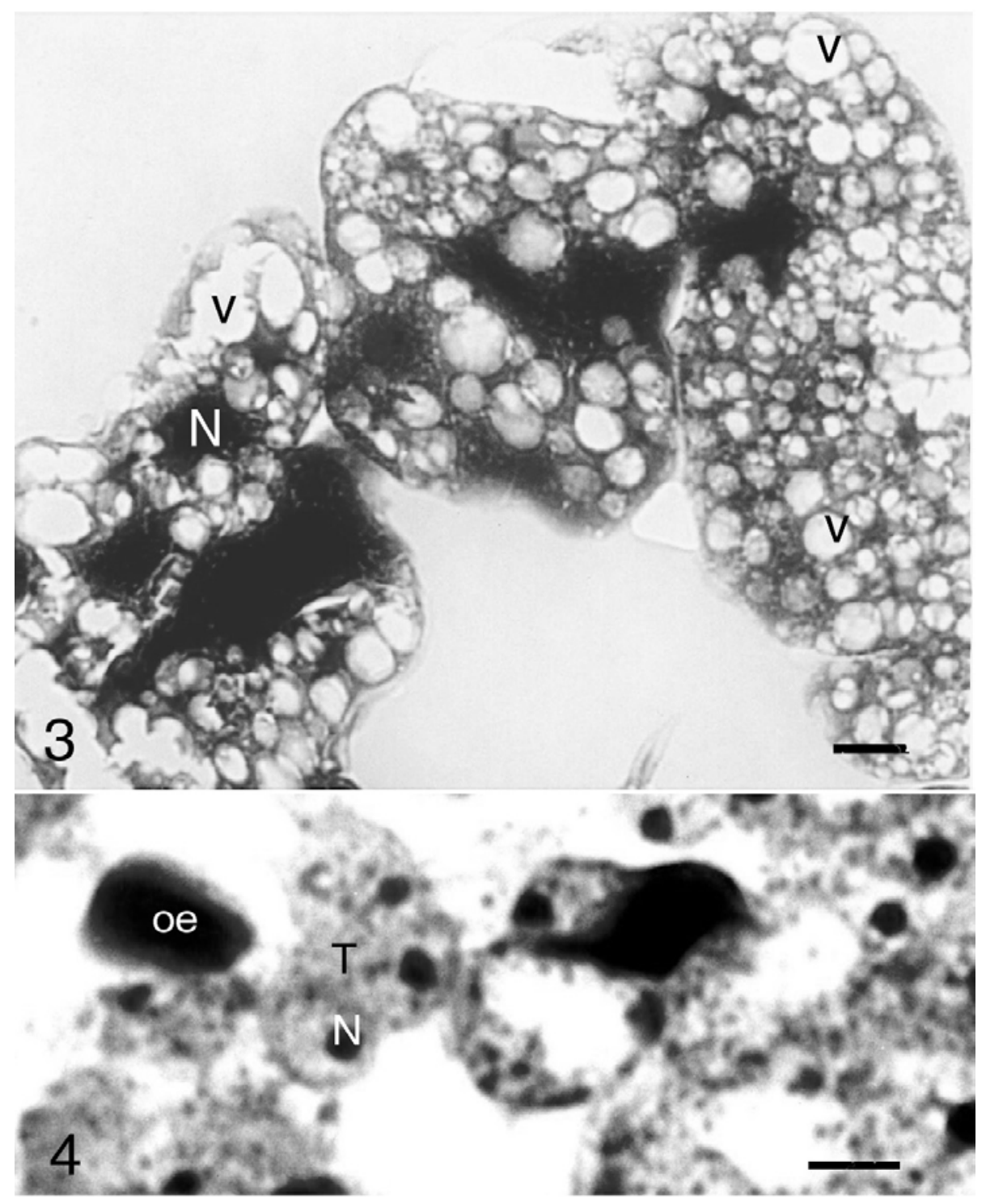

Figures 3-4 - Fat body of Eriopis connexa bromophenol blue stained. 3. Specimen fed with Myzus persicae showing positive reaction among vacuoles (v). 4. Specimens fed on Tetranychus evansi showing few positive cytoplasm granules. N - nucleus, oe oenocyte, $\mathrm{T}-$ trophocyte. Bars $=15 \mu \mathrm{m}$.

For lipids histochemical tests, specimens fed on aphids showed vacuoles blue and red indicating presence of acidic and neutral lipids, while in specimens fed with mites there was not a distinctive reaction being observed an uniform cytoplasm coloration suggesting the presence of few acidic lipids. This showed that E. connexa developed best feeding with aphids, due to the relative abundance in the masses of fat body, as well as in the highest stored nutrients and in the largest trophocyte size, when compared to the aspect of fat body in specimens fed with mites. According to Hoffmann and Frodsham (1993), coccinelids were generalist predators feeding on several prey types, mainly aphids, but when these became scarce they fed on eggs, small insect larvae, mites, nectar and honeydew. However, preliminary studies showed that individuals fed with aphids developed better, presenting shorter life cycle than specimens fed with others prey (unpublished data). 


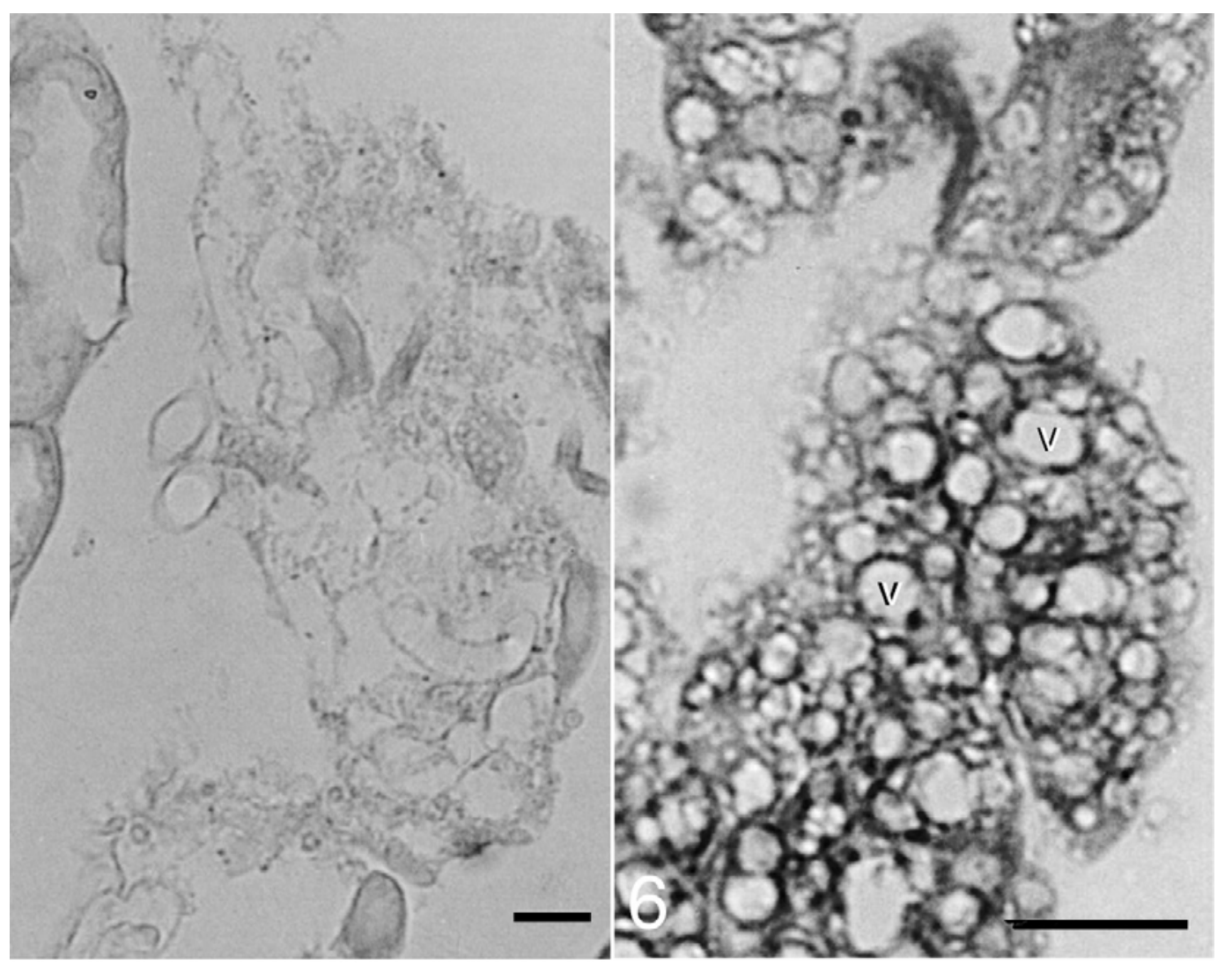

Figures 5-6 - Fat body (fb) of Eriopis connexa PAS stained. 5. Specimen fed with Tetranychus evansi showing weakly reaction. 6. Specimens fed on Myzus persicae showing positive reaction among vacuoles( $\mathrm{v})$. Bars $=15 \mu \mathrm{m}$.

This showed that aphid was the main or the favorite diet for this insect. In holometabolous insects, during larval cycle, trophocytes store large amounts of lipids, carbohydrates and proteins, which are mobilized to supply energy during the metamorphosis (Snodgrass 1935; Cruz-Landim 1983; Marx 1987). On the other hand, in adults a pick in fat body metabolism has been observed that coincides with yolk deposition in oocytes (Han and Bordereau 1982; Tadbowski and Jones 1979). Hoffmann and Frodsham (1993) have pointed out that these beetles adjust their life cycle according to aphids populations at United States of America, where it is known that coccinelids populations are active during the whole winter and also in the summer, if there are aphids availability. Therefore, fat body morphology herein presented suggested that mites were an inadequate diet for $E$. connexa, because it did not supply the necessary nutrients for insect development and reproduction.

\section{RESUMO}

Joaninhas são eficazes predadores de artrópodes atuando diretamente sobre certas pragas e alimentando-se de parte ou de todo o corpo da presa. Dentre os coccinelídeos, Eriopis connexa possui uma posição de destaque no controle de pulgões. Os coccinelídeos por serem predadores generalistas, apresentam uma variabilidade na escolha de presas, alimentando-se também de ácaros. No Brasil, trabalhos realizados com $E$. connexa, apenas relatam a sua ocorrência, sendo assim este trabalho objetivou investigar a influência de duas fontes alimentares: pulgões e ácaros, na morfologia do corpo gorduroso de $E$. connexa. Os resultados mostraram que as células do corpo gorduroso dos indivíduos alimentados com pulgões apresentaram áreas mais de três vezes superiores $\left(511 \pm 98,7 \mu \mathrm{m}^{2}\right)$ que as das células do corpo gorduroso de indivíduos alimentados com ácaros $\left(162 \pm 34,9 \mu \mathrm{m}^{2}\right)$. Além disso, testes histoquímicos demonstraram que a quantidade de 
nutrientes estocados no corpo gorduroso também foi superior em indivíduos alimentados com pulgões.

\section{REFERENCES}

Chapman, R. F. (1998), The Insects: structure and function. $4^{\text {th }}$ ed. Cambridge : Cambridge University Press.

Cruz-Landim, C. (1983), O corpo gorduroso da larva de Melipona quadrifasciata anthidioides Lep. (Apidae: Meliponinae). Naturalia, 8, 7-23.

Cruz-Landim, C. (1985), Modificações das células do corpo gorduroso de rainhas de Apis mellifera L. (Hymenoptera: Apinae). Ciência e Cultura, 37, 471-474.

Gassen, D. N. (1986), Parasitos, patógenos e predadores de insetos associados à cultura de trigo. EMBRAPA/CNPT. Passo Fundo. Circ. Téc. 1.

Hagen, K. S. (1976), Role of nutrition in insect management. Paper presented at Tall Timbers $6^{\text {th }}$ Conference on Ecological Animal Control by Habitat Management. pp. 221-226.

Hagen, K. S. (1962), Biology and ecology of predaceous Coccinellidae. Ann. Rev. Entomol., 7, 289-326.

Han, S. H. and Bordereau, C. (1982), Ultrastructure of the fat body of reproductive pair in higher termites. J. Morphol., 172, 317-320.

Hodek, I. (1973), Biology of Coccinellidae. Academic Sciences, Prague.

Hoffmann, M. P. and Frodsham, A. C. (1993), Natural enemies of vegetable insects pests. Cooperative Extension, Cornell University, Ithaca, NY. http://www.nysaes.cornell.edu/ent/biocontrol/predato rs/hippodamia.html. 20/10/2000.

Holling, C. S. (1961), Principles of insect predation. Annu. Rev. Entomol., 6, 163-182.

Levenbook, L. (1985), Storage proteins. In: Gilbert, L. I. and Kerkut, G. (eds.). Comprehensive Insect Biochemistry, Physiology and Pharmacology. Oxford : Pergamon Press. pp. 307-346.

Marx, R. (1987), Changes in the fat body ultrastructure during the fifth larval instar in workers, queens and drones of the honey bee, Apis mellifera L. In: Eder, J. and Rembold, N. (eds.). Chemistry and Biology of Social Insects. Berlin : Peperny Verlag München. pp. 86-87.

Pimenta, H. R. and Smith, J. G. (1976), Afídeos, seus danos e inimigos naturais em populações de trigo (Triticum sp.) no Estado Paraná. OCEPAR, 175 pp.

Qin, W.; Yin, C. and Stoffolano Jr., J. G. (1997), Control of pupal fat body disappearance in the female black blow fly, Phormia regina (Meigen) by the brain and the corpus allatum. J. Insect Phisiol., 43, 533-540.
Santos, G. P. and Pinto, A. C. Q. (1981), Biologia de Cycloneda sanguinea e sua associação com pulgão em mudas de Mangueira. Pesq. Agropec. Bras., 16, 473-476.

Snodgrass, R. E. (1935), Principles of insect morphology. New York; London : Macgraw-Hill Book Company.

Tadbowski, J. M. and Jones, J. C. (1979), Changes in fat body and oocytes during starvation and vitellogenesis in mosquito, Aedes aegypti (L.). J. Morphol., 179, 185-264.
Received: June 18, 2002; Revised: June 04, 2003; Accepted: August 18, 2003. 